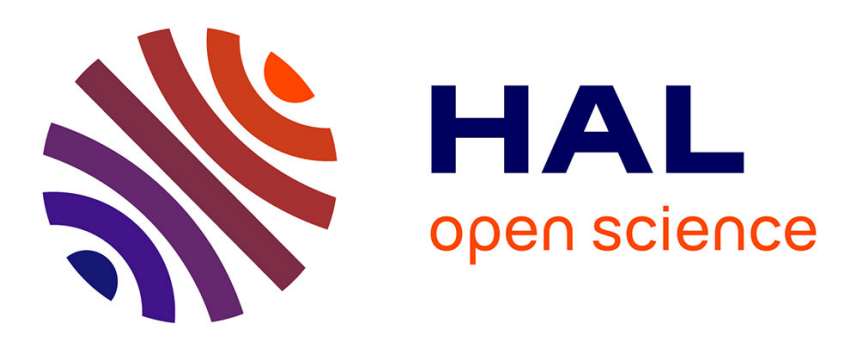

\title{
The Appearance of Xylophagy in Cockroaches: Two Case Studies with Reference to Phylogeny \\ Philippe Grandcolas
}

\section{To cite this version:}

Philippe Grandcolas. The Appearance of Xylophagy in Cockroaches: Two Case Studies with Reference to Phylogeny. Journal of orthoptera research, 1995, 4, pp.177-184. 10.2307/3503473 . hal-01368899

\section{HAL Id: hal-01368899}

\section{https://hal-univ-rennes1.archives-ouvertes.fr/hal-01368899}

Submitted on 23 Nov 2017

HAL is a multi-disciplinary open access archive for the deposit and dissemination of scientific research documents, whether they are published or not. The documents may come from teaching and research institutions in France or abroad, or from public or private research centers.
L'archive ouverte pluridisciplinaire HAL, est destinée au dépôt et à la diffusion de documents scientifiques de niveau recherche, publiés ou non, émanant des établissements d'enseignement et de recherche français ou étrangers, des laboratoires publics ou privés. 


\title{
The Appearance of Xylophagy in Cockroaches: Two Case Studies with Reference to Phylogeny
}

\author{
PhilipPe GrandColas
}

URA 373 CNRS, Laboratoire de Primatologie-Biologie evolutive, Station Biologique de Paimpont, F-35380 Paimpont, FRANCE

ABSTRACT.-Xylophagy in cockroaches has been considered a rare attribute, inherited from a common ancestor with termites. This point of view is discussed in a phylogenetic perspective for two independent tropical cockroach lineages: the subfamily Polyphaginae and the group (Zetoborinae + Blaberinae + Gyninae + Diplopterinae). A phylogeny was constructed for each of these two lineages. Xylophagy occurs in Cryptocercus in the subfamily Polyphaginae and has recently been discovered in Parasphaeria (subfamily Zetoborinae). This allows one to propose, in reference to phylogenies, that xylophagy is recently derived, that slow development is a correlate of xylophagy rather than a prerequisite, and that xylophagy appearance preceded the conquest of temperate areas at least once.

\section{INTRODUCTION}

Xylophagy and flagellate symbionts usually have been viewed as ancestral traits in Dictyoptera (Cleveland et al. 1934, Grassé and Noirot 1959, Nalepa 1984) as well as in Isoptera (Grassé and Noirot 1959, Noirot 1992, Wilson 1971). This assumption was made in reference to the so-called "primitive nature" of the xylophagous taxa (the cockroach Cryptocercus Scudder, 1862, and "lower" termites), which were supposed to show numerous relictual features inherited from some very ancient ancestors. More recently, the evolution of xylophagy in Dictyoptera was studied relative to an independent phylogeny (Hennig 1981, Deleporte 1988). This allows one to consider the evolution of xylophagy with less a priori arguments and to avoid reconstructing a history consistent with previous ideas about the "primitive xylophagous taxon" concept. The evolutionary scenario of xylophagy in Dictyoptera and Isoptera depended heavily on the phylogenetic position of the xylophagous cockroach, Cryptocercus. This last taxon was until recently considered the sister-group of all other cockroaches (Deleporte 1988, Thorne and Carpenter 1992). For this reason, xylophagy and the presence of symbionts were for a time thought to be present in a common ancestor of Cryptocercus and some termites. Some authors favored different hypotheses, including a possible convergence and a transfer of flagellates between Cryptocercus and some termites (Emerson 1935, Boudreaux 1979, Thorne 1990). But they based their hypotheses on the old phylogenetic position of Cryptocercus, and even recently, Thorne (1990) considered xylophagy and the function of symbionts as very ancient and having occurred in "roachoid and termitoid lines", "millions of years ago".

Recently, Grandcolas and Deleporte (1992) and Grandcolas (in press) showed that treating Cryptocercus as the sister group to all other cockroaches was due to a lack of discovered synapomorphies and to a biased sampling of other cockroach families. A new phylogenetic position was proposed after the diseovery of numerous synapomorphies and leads to a new hypothesis on the evolution of xylophagy.

Xylophagy was decidely misrepresented in cockroaches and its origin is still not well understood; but it is also more common than previously considered. It was previously known in Cryptocercus and also in several genera of the subfamily Panesthiinae (Chopard 1938, Roth and Willis 1960). But recently two other cases of xylophagy were recently discovered in the subfamilies Nyctiborinae and Zetoborinae (Grandcolas 1993c, Grandcolas, Desutter-Grandcolas, in prep.).

New phylogenetic studies and a comparison of several different cases could enhance our understanding of xylophagy in cock- roaches. Using a phylogenetic framework, I here study the evolution of xylophagy in two lineages, the subfamilies Polyphaginae and Zetoborinae. I test whether xylophagy is ancestral or derived, whether peculiar life histories are correlates or prerequisites for xylophagy evolution, and whether xylophagy followed or preceded the conquest of temperate areas. A climatic analysis of distributional patterns is also performed in xylophagous taxa and in their common ancestors.

\section{MATERIAL AND METHODS}

\section{Studied lineages}

(Zetoborinae + Blaberinae + Gyninae + Diplopterinae) is a tropical worldwide monophyletic group, prevalent in forested regions (Grandcolas 1993d) and belonging to the family Blaberidae. The first two subfamilies are Neotropical, whereas the last two ones are African and Australasian, respectively. Phylogeny at the generic level is based on Grandcolas (1993d). In this lineage, one genus, Parasphaeria Brunner v. W., 1865, comprises xylophagous species in the austral part of South America (Grandcolas, DesutterGrandcolas, in prep.).

The subfamily Polyphaginae is also a worldwide tropical group (Grandcolas and Deleporte 1992, Grandcolas 1994) in the family Polyphagidae. It is present in the deserts of all continents (excluding those of Australia) (Grandcolas in prep., contra Mackerras 1968) and in dry forests and rainforests of Africa and Asia. Its phylogeny at the generic level is obtained from Grandcolas (1994). Only the genus Cryptocercus in this subfamily contains xylophagous species (Cleveland et al. 1934, Bey-Bienko 1950).

\section{Ecological attributes}

Ecological attributes are features in which a priori homology and polarization are so hazardous that one prefers to make these operations in relation to an independent phylogeny (Grandcolas 1991). Each attribute may display several possible states and is coded in a non-additive way (Farris 1988). Unknown states are indicated with a question mark. When an attribute in a genus presents several states in different species, it is coded as polymorphic. When it consists of several states in the same species, it is coded as another and supplementary state. Ecological attributes are based either on my own field and laboratory observations (in French Guiana, Gabon, Saudi Arabia) or on literature records. The state of an attribute in a genus is considered as known if at least one species has been observed. This assumption appears reasonable, because $17 \%$ of genera are monospecific and $31 \%$ of the genera have several or all species with known and similar life habits. Two attributes are studied in relation to phylogeny in addition to 
xylophagy, namely the occupation of a particular biome (Grandcolas 1993b), and life-history characteristics (development duration). Xylophagy consists of two states: non-xylophagous and xylophagous. Occupancy of a particular biome is defined after distribution reports which are then compared with vegetation maps (Cochrane 1963, Unesco 1981, White 1986, Whitmore 1984, Ying 1983). Biome occupancy is defined as follows: for the first lineage, occupation of tropical rainforest (including both montane and lowland rainforests), dry and open woodlands (including Acacia bush, cerrado, caraib xerophytic forest), savanna, temperate forest, (Grandcolas 1993b), and for the second lineage: tropical forest (including both rain and dry forests), temperate forest, desert, and desert and temperate forest together. Development duration is arbitrarily defined as comprising two states: short development (less than 400 days from hatching to adult) versus long development (more than 400 days from hatching to adult). Laboratory rearing under standard conditions provide some estimates (Grandcolas 1993a, pers. obs., and literature, $c f$ infra).

\section{Inference of evolutionary scenarios}

Evolutionary scenarios of attributes are inferred from the phylogeny. Biological attributes and phylogenetic characters are then two independent data sets. The method, called "character optimization" (Farris 1970), is applied to attributes using strict parsimony, as recommended by Brooks and McLennan (1991). The attribute states are mapped on the existing phylogeny and the most parsimonious evolutionary scenario(s) among all those possible is chosen: it consists of placing each state of an attribute at the root of the tree and then computing the subsequent number of changes necessary to obtain the present state distribution in existing taxa. The scenario(s) requiring the smallest number of evolutionary changes of attribute states is (are) kept as the best estimate of the course of evolution. The value of phylogenetic hypotheses, including associated scenarios, lies only in the evidence of its smallest number of steps relative to others, notwithstanding testing statistics and random models with unrealistic covering assumptions (Carpenter 1992). The most parsimonious scenario is taken as the more likely hypothesis. Alternative scenarios simply need more data to be reexamined.

\section{Climatic analysis}

The distributional patterns of cockroaches are compared to the climatic maps of North and South America and of Asia (UNESCO, WMO 1975, 1979, 1981). The localities were taken from the literature and from my personal data. Only annual mean temperature and annual total rainfall are considered. The isohyet nearest to the border of the distribution areas is considered as a tentative climatic limit.

\section{RESULTS}

Xylophagy was suspected by Grandcolas (1991) in the genus Parasphaeria which belongs to the subfamily Zetoborinae in the group Zetoborinae + Blaberinae + Gyninae + Diplopterinae. This was recently confirmed by field and laboratory observations (Grandcolas, Desutter-Grandcolas, in prep). Xylophagy has been known for a long time in Cryptocercus (Cleveland et al. 1934) of the subfamily Polyphaginae. The most parsimonious scenario about xylophagy indicates that it appeared once in each lineage - in the ancestor of Parasphaeria for the first lineage, and in the ancestor of Cryptocercus for the second lineage (Figs. 1, 2). This scenario implies for each lineage a single step. A converse and less parsimonious scenario requires five steps under the hypothesis of an ancestral inheritance followed by several losses.

The length of development was observed to vary in different groups, ranging from two months to several years (Table 1). When total development time was not known, a minimal estimate was computed on the basis of five times the mean instar duration. The smallest number of instars known for ovoviviparous species is

Table 1. Mean durations of development (days $\pm S E$ ) in taxa belonging to (Zetoborinae + Blaberinae + Gyninae + Diplopterinae) and to Polyphaginae, with the origin of data (mean duration of one instar, when total duration not known).

\begin{tabular}{|c|c|c|}
\hline Taxon & Duration of Development & Source \\
\hline Blaberus craniifer & 245 & Lefeuvre (1963) \\
\hline Byrsotria fumigata & 276 & Lefeuvre (1969) \\
\hline Diplotera punctata & 46 & Schal et al. (1984) \\
\hline Gyna sp. & about 100 & Pers. obs. \\
\hline Hyporhicnoda litomorpha & 307 & Lefeuvre (1969) \\
\hline Lanxoblatta emarginata & $349 \pm 3$ & Grandcolas (1993e) \\
\hline Parasphaeria sp. & $\begin{array}{l}\text { more than } 150 \\
\text { for any instar }\end{array}$ & Pers. obs. \\
\hline Paradicta rotunda & about 360 & Pers. obs. \\
\hline Phortioeca nimbata & $188.5 \pm 2.5$ & Grandcolas (1993e) \\
\hline Schultesia lampyridiformis & $77.2 \pm 19.5$ & Grandcolas (1993e) \\
\hline Thanatophyllum akinetum & $335 \pm 26.4$ & Grandcolas (1993e) \\
\hline Arenivaga tonkowa & about 150 & Cochran (1979) \\
\hline Cryptocercus punctulatus & more than 2000 & $\begin{array}{l}\text { Cleveland et al. (1934); } \\
\text { Nalepa (1984) }\end{array}$ \\
\hline Ergaula capensis & $\begin{array}{l}\text { less than } 30 \\
\text { for any instar }\end{array}$ & Pers. obs. \\
\hline Heterogamisca chopardi & $\begin{array}{l}\text { less than } 30 \\
\text { for any instar }\end{array}$ & Pers. obs. \\
\hline Polyphaga aegyptiaca & $\begin{array}{l}\text { less than } 30 \\
\text { for any instar }\end{array}$ & Pers. obs. \\
\hline Therea petiveriana & less than 300 & Pers. obs. \\
\hline
\end{tabular}




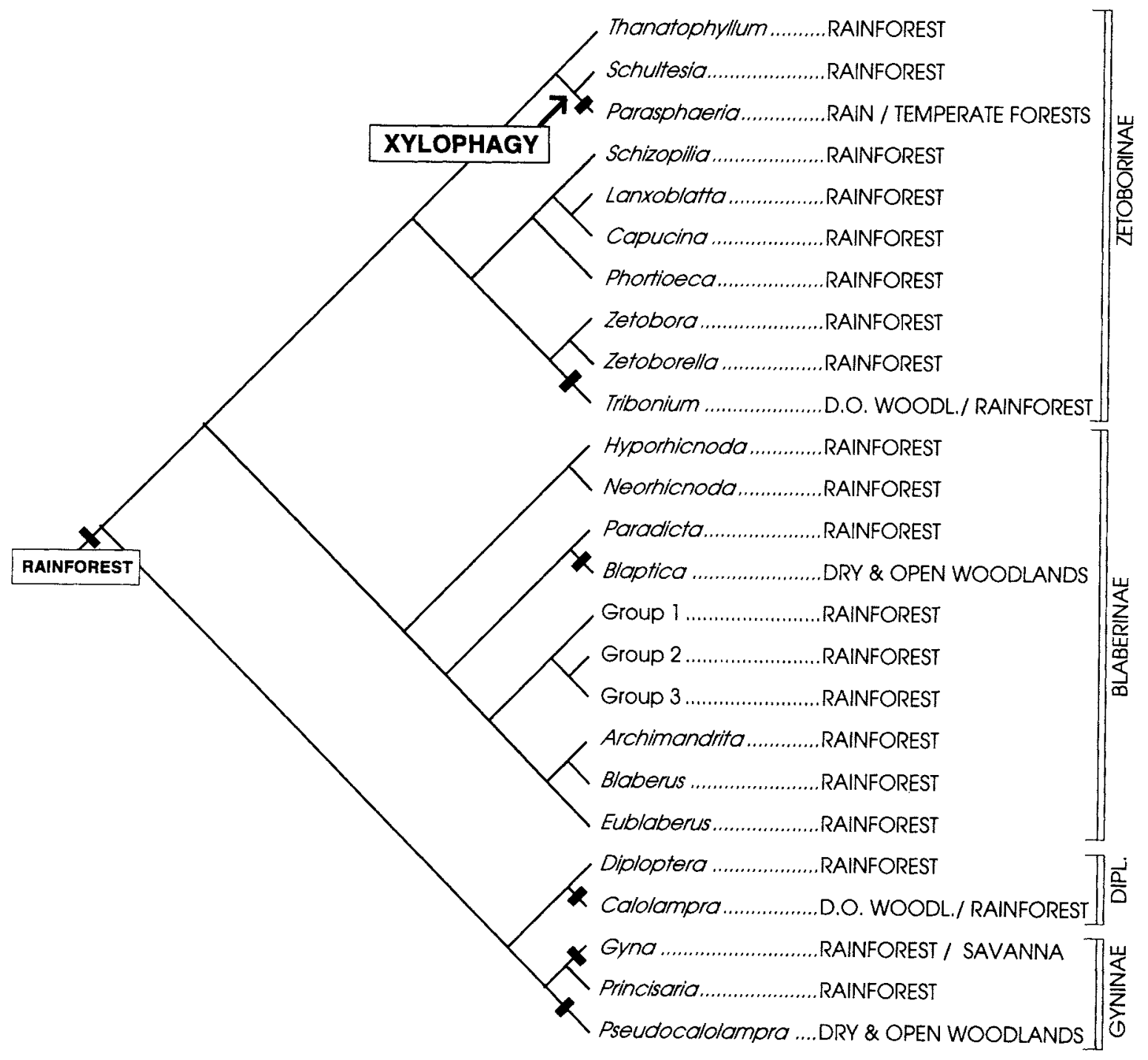

Fig. 1. Character optimization of biome occupancy upon the phylogeny of (Zetoborinae + Blaberinae + Gyninae + Diplopterinae). A change of biome occupancy is shown with a thick line. The ancestral state is inferred "rainforest". The inferred appearance of xylophagy is indicated by a label.

five (e.g., Lefeuvre 1969, Schal et al. 1984). Nevertheless, most development times were equal to or less than 400 days, and only the two xylophagous taxa had development times of more than 400 days. In reference to the phylogenies, the long development appears to have evolved independently for Parasphaeria and Cryptocercus and therefore requires one step each time (Figs. 3, 4). The converse scenario, taking long development as an ancestral state, supposes five steps each time.

Biome occupancy was already analysed in Grandcolas (1993b) for the group (Zetoborinae + Blaberinae + Gyninae + Diplopterinae) and occupancy of "rainforest" was hypothesized to be ancestral implying only six steps against twelve steps for the second most parsimonious scenario (Fig. 2). Biome occupancies for the subfamily Polyphaginae are shown in Figure 1. Five different biomes were occupied and five genera occupied two different biomes. The most parsimonious scenario implies that desert occupancy is ancestral and that four changes subsequently occurred. In these scenarios, the occupation of temperate biomes (temperate forest) appeared secondarily in some species of Parasphaeria and all species of Cryptocercus.

Distribution of xylophagous taxa and of their nearest ances- tors are depicted on maps in which some annual climatic isohyets are shown (Figs. 5,6). The occupation of temperate forests corresponds in xylophagous taxa of both lineages to spreading respectively beyond the $5^{\circ} \mathrm{C}$ and $10^{\circ} \mathrm{C}$ isotherms. The xylophagous taxa contrary to their nearest parents do not spread beyond the isohyet $1200 \mathrm{~mm}$.

An estimate of the relative timing of all these evolutionary events may be obtained when the three evolutionary scenarios are combined. Xylophagy appeared first, together with long developmental time; in one case the spread to temperate forests occurred secondarily .

\section{DISCUSSION}

Xylophagy appears to have evolved independently in the subfamilies Polyphaginae and Zetoborinae. This invalidates the classical scenario of ancestral xylophagy involving Cryptocercus (Cleveland et al. 1934, Grassé and Noirot 1959, Nalepa 1984), as already noted by Grandcolas and Deleporte (1992). It is probable then that xylophagy and flagellate symbionts evolved independently in Cryptocercus, by convergence and transfer, respectively, 


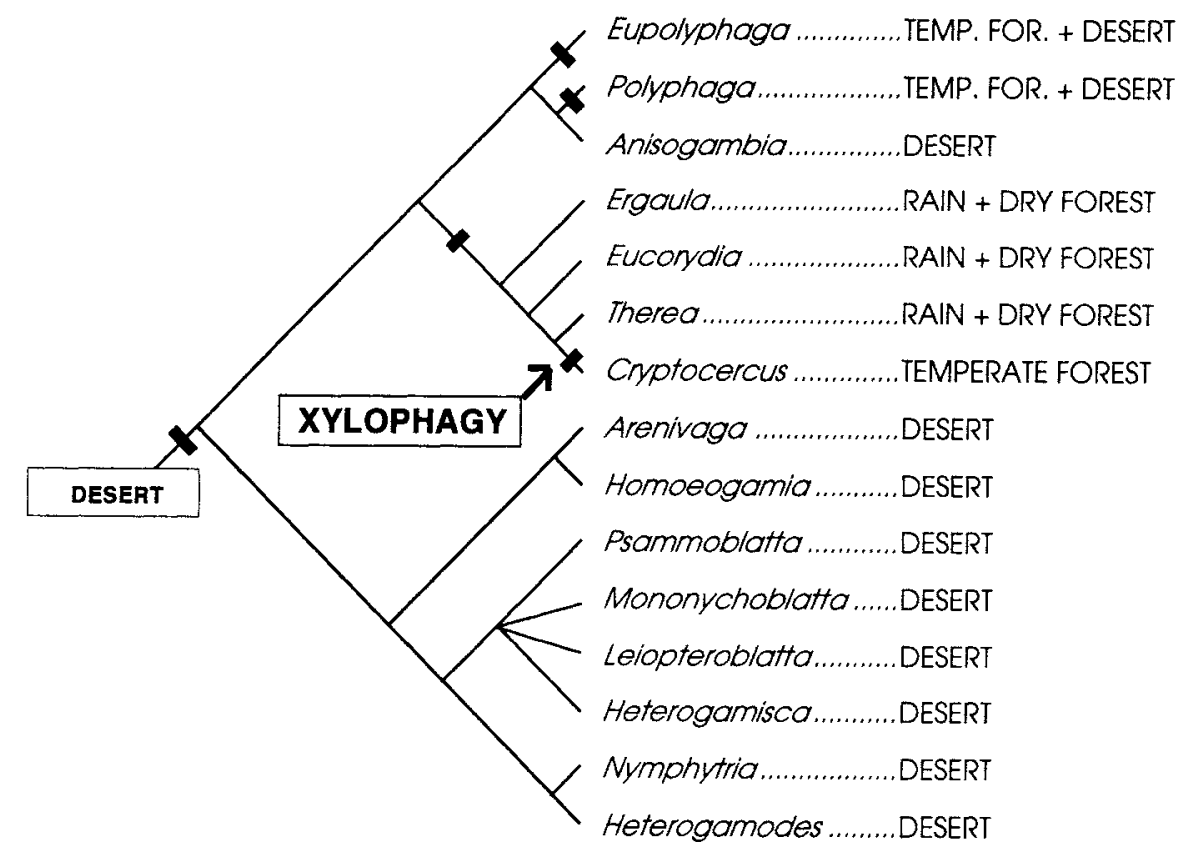

Fig. 2. Character optimization of biome occupancy upon the phylogeny of subfamily Polyphaginae. A change of biome occupany is shown with a thick line. The ancestral state is inferred "desert". The inferred appearance of xylophagy is indicated by a label.

and that the similarity with mastotermitid termites and other wood-eating Isoptera is due to convergence. Another scenario was proposed by several workers (Emerson 1935, Boudreaux 1979. Thorne 1990) was the unsupported hypothesis of an ancient but independent appearance of xylophagy in Cryptocercus. This last scenario is also improbable, since it is based on the now discredited older phylogenetic position of Cryptocercus. The new phylogenetic position does not allow one to consider Cryptocercus as a relictual taxon which would have inherited a very ancient xylophagy from an ancestor shared with the early termites. Cryptocercus has many closely related ancestors, and geographical vicariances among all these taxa do not allow one to consider that the ancestor of Cryptocercus to be so ancient (Grandcolas 1994). One may consider that Hennig (1981) was probably correct, when he hypothesized on the probable recent origin of xylophagy in Cryptocercus.

Xylophagy has many life-history correlates (Haackand Slansky 1987). A wood diet generally leads to a dearth of available nitrogen, even if xylophagous species have symbionts or endocellulases which digest cellulose (Cleveland et al. 1934, Scrivener et al. 1989). A nitrogen scarcity has been hypothesized to slow down development (Haack and Slansky 1987; Nalepa 1988, 1990), a prediction which seems to be verified in the two cockroach lineages under study: xylophagous taxa have very long development times while related but nonxylophagous taxa have shorter ones.

One could, however, argue that xylophagous taxa develop slowly, because they inhabit temperate regions. In a seasonal and cold environment, two life-history strategies could occur: a) maximizing the development rate within the favorable season or b) maximizing nutrient uptake within several seasonal cycles (Denno and Dingle 1981). It is then necessary to compare the three scenarios to see if long development was acquired together with xylophagy before a shift into temperate areas. The diversification in biome occupation was different in the two lineages. In (Zetoborinae + Blaberinae + Gyninae + Diplopterinae), the ancestor probably inhabited the rainforest and several changes led to occupation of other biomes, except deserts. These changes did not involve many groups within the lineage. Polyphagines originally occupied the desert biomes, and the lineage is still prevalent there. Repeated changes occurred in one part of the lineage, leading to the successive conquest of both dry forests and rainforests, and then of temperate forests. The transition to temperate forests occurred in both lineages in the ancestors of extant xylophagous taxa. The phylogenetic pattern shows that in Parasphaeria slow development should be hypothesized to appear before a spread into temperate areas. A consideration of all the evolutionary scenarios does not allow one to fully resolve the question: in only one case a xylophagous taxon seems to have acquired slow development before it spread in a temperate biome. In the other case, the three evolutionary events appear simultaneously and the comparison of scenarios does not provide information.

Why do xylophagous species have such peculiar climatic distributions and sometimes inhabit temperate areas, especially when these areas are cold and humid? Slow development, if it preceded the occupation of temperate zones, could have provided a selective advantage against seasonality and coldness. Sexual maturity could be attained within several seasons. Conversely, with a short development maturity could be attained at the end of the first season, but adults may be unable to reproduce before the following unfavorable season. This hypothesis, however, presupposes that slow developing species are cold-resistant to pass through cold period, that this has been proved only in the species Cryptocercus punctulatus Scudder (Hamilton et al. 1985). Another possibility is the appearance of a diapause for adults, larvae, or eggs in rapidly developing species. But the prevalence of diapause occurrency is unknown in cockroaches, apart from the family Blattellidae (Brown 1980). A long development time in the present hypothetical context would appear to be an exaptative attribute (Gould and Vrba 1982), i.e., it could have been selected in a nutritional context but have a selective value in a climatic context. 


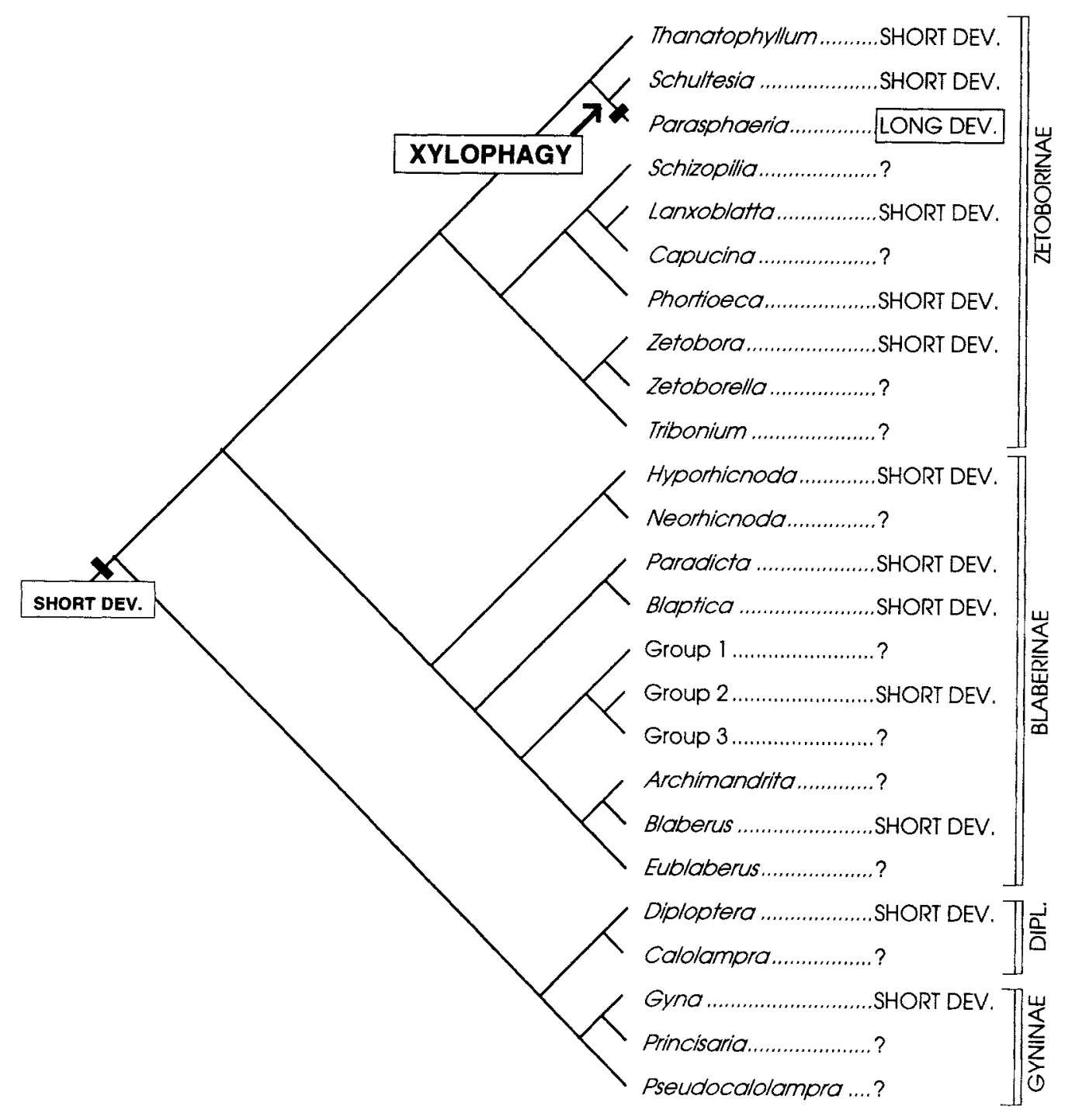

Fig. 3. Character optimization of short versus long development upon the phylogeny of subfamily (Zetoborinae + Blaberinae + Gyninae + Diplopterinae). A change of state is shown with a thick line. The ancestral state is inferred "short development".

This context does not explain why xylophagous species of both studied lineages are limited to especially humid areas. Wood quality is known to vary with its moisture content (Haack and Slansky 1987), and it should be tested in the future to see if these xylophagous cockroaches require wood with an especially high moisture content. Such a requirement could explain why xylophagous species are limited to very humid areas.

This study is only a preliminary work for clarifying the study of xylophagy in cockroaches. More data are needed to examine in detail the attributes and the evolutionary scenarios. More case studies are also necessary to test the hypotheses emerging from these scenarios. The study of xylophagy has until now suffered from the poor knowledge regarding the phylogeny of the involved xylophagous taxa and from a priori ideas concerning these taxa.

Three facts are very important in my opinion to enhance this study. Firstly, a priori ideas about evolutionary scenarios should be abandoned, especially those involving the concept of "primitive taxon". This concept is particularly misleading because it leads to dependent and circular reasoning (Dawkins 1987) and has no place in phylogenetic studies (Nelson 1989). Secondly, evolutionary scenarios gain credence only with reference to a phylogeny: this allows one to study the polarity, number, and relative position of evolutionary events and to minimize a priori statements (Carpenter 1989, Coddington 1988, Deleporte 1988, Grandcolas 1991). Thirdly, workers should not focus solely on Cryptocercus; but they should try to consider other xylophagous taxa (e.g., Matsumoto 1987, 1988). They could consider, therefore, not only homology when using the phylogenetic reference but also analogy, when comparing several independent case studies: the comparison of several independent and then analogous scenarios is a way to test the generality of evolutionary hypotheses (Grandcolas 1991).

\section{ACKNOWLEDGMENTS}

I am indebted to P. Deleporte and L. Desutter for reading my manuscript. I thank N. Kristensen, L. M. Roth, L. Matile for their 


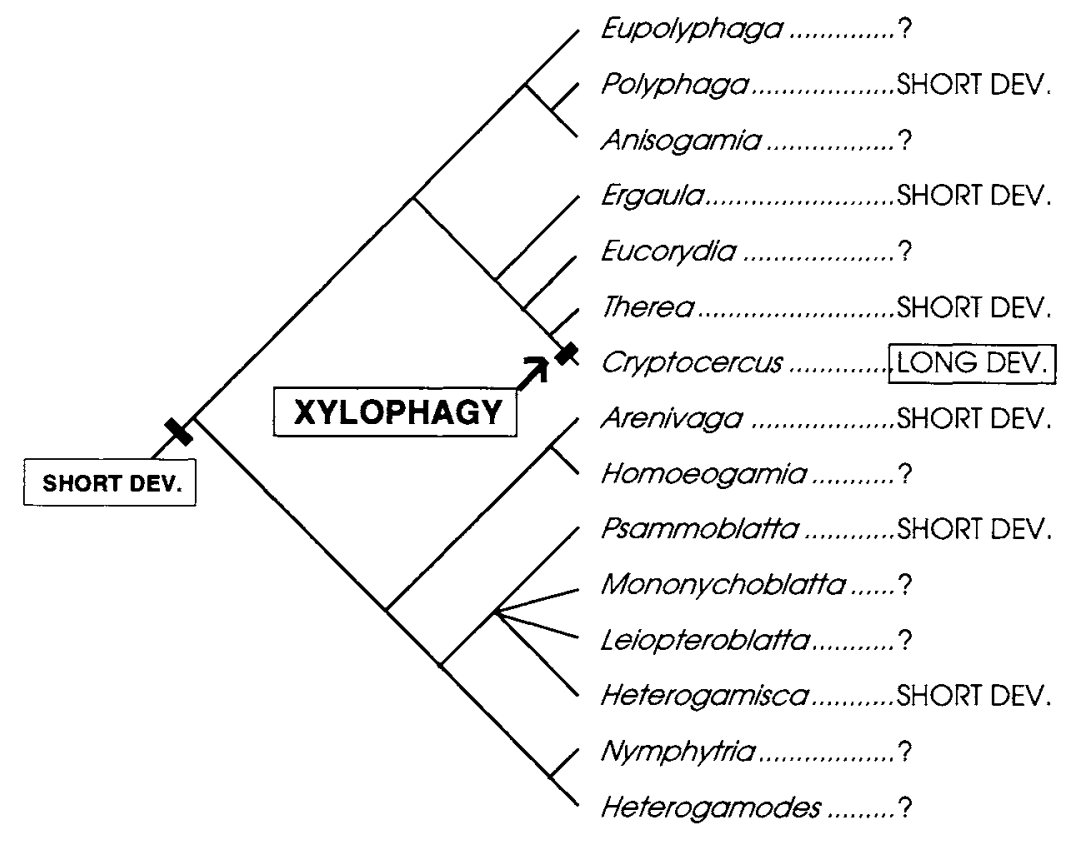

Fig. 4. Character optimization of short versus long development upon the phylogeny of subfamily Polyphaginae. A change of state is shown with a thick line. The ancestral state is inferred "short development".

comments on the phylogenetic studies on which is based the present study. Field work was made possible with Action specifique of Museum de Paris and program SOFT of Ministere de ltenvironnement (French Guiana), the NWRC guest researcher program (Saudi Arabia), and IRET assistance (Gabon). I thank the curators of institutions which loan to me some specimens. The work has been supported by URA CNRS 373 in Laboratoire de Primatologie-Biologie evolutive and I have had access to the national insect collections in Paris Museum.

\section{LITERATURE CITED}

Bey-Bienko GI. 1950. Fauna of the USSR. Insects. Blattodea. Inst. Zool. Acad. Sc. USSR, Moscow.

Boudreaux HB. 1979. Arthropod Phylogeny with Special Reference to Insects. John Wiley and Sons, New York.

Brooks DR, McLennan DA. 1991. Phylogeny, Ecology, and Behavior. A Research Program in Comparative Biology. The University of Chicago Press. Chicago, IL.

Brown VK. 1980. Developmental strategies in Ectobius pallidus (Dictyoptera: Blattidae). Int. J. Invert. Reprod. 2: 85-93.

Carpenter J. 1992. Random cladistics. Cladistics 8: 147-153.

Chopard L. 1938. La biologie des Orthopteres. XX. Encyclopedie entomologique. Lechevalier. Paris.

Cleveland LR, HallSR, Sanders EP, Collier J.1934. The woodfeeding roach, Cryptocercus, its Protozoa and the symbiosis between Protozoa and roach. Mem. Am. Acad. Arts and Sci. 17: 185-342.

Cochrane GR. 1963. A physiognomic vegetation map of Australia. I. Ecol. 51: 639-655.

Dawkins, R. 1987. Evolution. pp. 153-159. In: D McFarland (ed.). The Oxford Companion of Animal Behaviour. Oxford University Press, Oxford.

Deleporte, P. 1988. Etude éco-éthologique et évolutive de P. americana et d'autre blattes sociales. These, Universite de Rennes I.

Denno RF, Dingle H. 1981. Insect life-history patterns: habitat and geographic variation. Springer-Verlag. New York.

Emerson AE. 1935. Symbiosis between roaches and protozoa. Review of L. R. Cleveland monograph. Ecology 16: 116-117.
Farris JS. 1970. Method for computing Wagner trees. Syst. Zool. 19: 83-92.

Farris JS. 1988. Hennig86, version 1.5. Computer program and documentation. Port Jefferson Station. New York.

Gould SJ, Vrba ES. 1982. Exaptation-a missing term in the science of form. Paleobiology 8: 4-15.

Grandcolas P. 1991. Les Blattes de Guyane Francaise: Structure du peuplement et etude eco-ethologique des Zetoborinae. Thèse. Universite Rennes I.

Grandcolas P. 1993a. Habitats of solitary and gregarious Zetoborinae (Insecta, Blattaria, Blaberidae). Neotrop.Stud. Fauna Environ. 28: 179-190.

Grandcolas P. 1993b. The origin of ecological diversity in a tropical cockroach lineage: a phylogenetic analysis. Acta Oecologica 14: 259-270.

Grandcolas P. 1993c. Le genre Paramuzoa Rehn 1973: sa présence en Amazonie Guyanaise et un cas de xylophagie chez les Nyctiborinae (Dictyoptera, Blattaria). Bull. Soc. ent. Fr.98: 131138.

Grandcolas P. 1993d. Monophylie et structure phylogénétique des (Zetoborinae + Blaberinae + Gyninae + Diplopterinae) (Dictyoptera, Blattaria, Blaberidae). Ann.Soc. entomol.Fr. (N.S.) 29: 195-222.

Grandcolas P. 1994. Phylogenetic systematics of the subfamily Polyphaginae with assignment of Crysrtocerezzs to this taxon. Syst. Entomol. 19: 145-158.

Grandcolas P, Deleporte P. 1992. La position systématique de Cryptocercus Scudder, 1862 et ses implications évolutives. C. $R$. Acad. Sc. Paris 315: 317-322.

Grassé PP, Noirot C. 1959. L'évolution de la symbiose chez les Isoptères. Experientia 15: 365-372.

Haack RA, Slansky F. 1987. Nutritional ecology of wood feeding Coleoptera, Lepidoptera, and Hymenoptera. pp. 449-486, In: $\mathrm{F}$ Slansky and JG Rodriguez (eds.). Nutritional ecology of insects, mites, spiders and related invertebrates. Wiley and Sons. New York.

Hamilton RL, Mullins DE, Orcutt DM. 1985. Freezing tolerance in the wood cockroach Cryptocercus punctulatus (Scudder). Experientia 41: 1535-1537. 


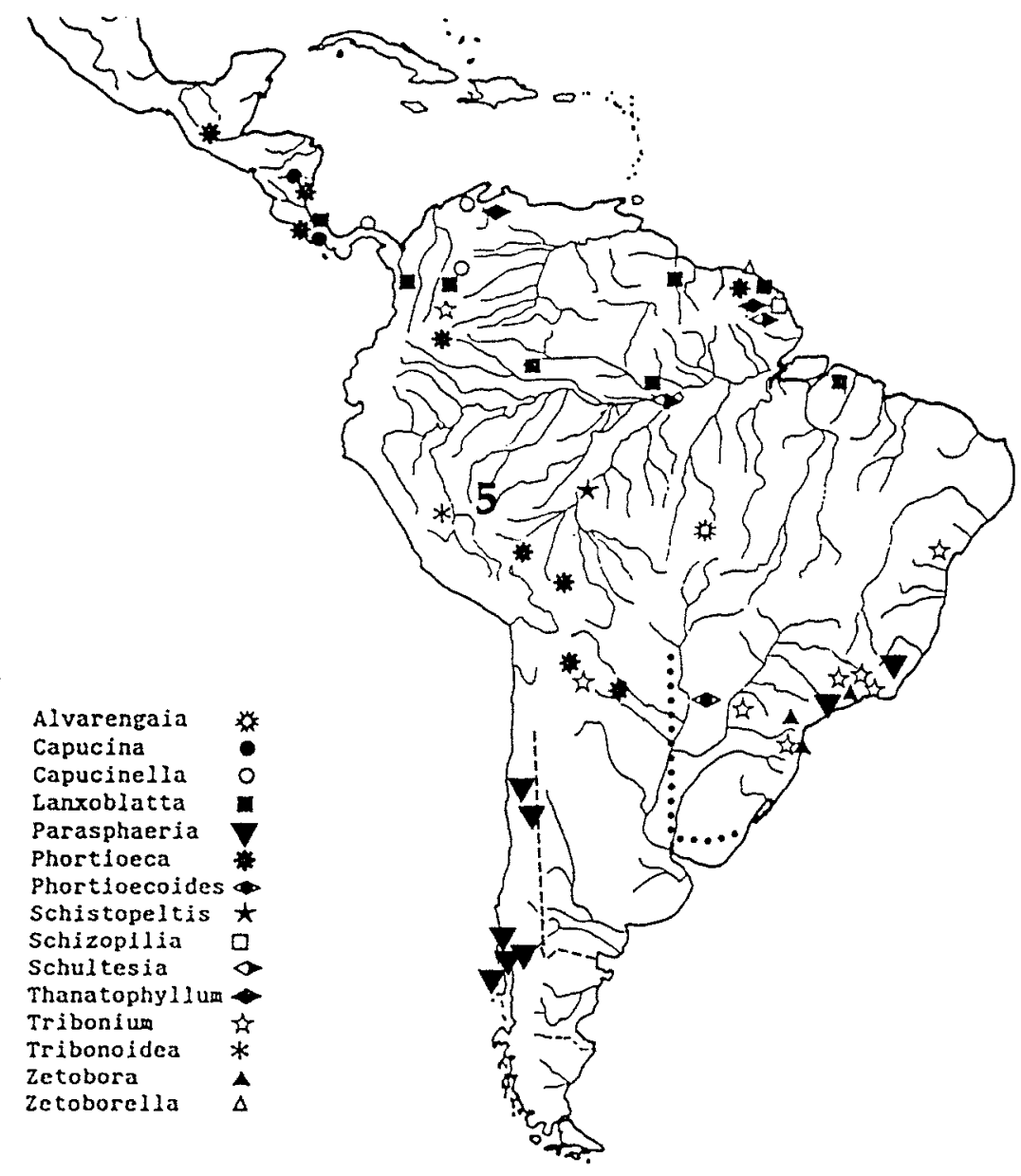

Fig. 5. Distribution map of the genera of the subfamily Zetoborinae in South and Central Ameriea. The isohyetes which indicate respectively annual means of $10^{\circ} \mathrm{C}$ (dashed line) and $1200 \mathrm{~mm}$ (dotted line) are placed on the map.

Hennig W. 1981. Insect Phylogeny. John Wiley and Sons. New York. Lefeuvre JC. 1969. Recherches sur les organes alaires des Blattaria. Thèse, Universite de Rennes.

Mackerras MJ. 1968. Polyphagidae from eastern Australia. J. Aust. Entomol. Soc. 7: 147-154.

Matsumoto T. 1987. Colony composition of the subsocial woodfeeding cockroaches Salganea taiwanensis Roth and $S$. esakii Roth (Blattaria: Panesthiinae). pp. 394, In: J Eder and H Rembold (eds.). Chemistryand Biology of social insects. Proceedings 10th Congress International Union of the Study of Social Insects. Verlag J. Peperny. Munchen.

Matsumoto T. 1988. Colony composition of the wood-feeding cockroach, Panesthia australis Brunner (Blattaria, Blaberidae, Panesthiinae) in Australia. Zool. Sc. 5: 1145-1148.

Nalepa CA. 1984. Colony composition, protozoan transfer and some life history characteristics of the woodroach Cryptocercus punctulatus Scudder (Dictyoptera:Cryptocercidae). Behav. Ecol. Sociobiol. 14: 273-279.

Nalepa CA. 1988. Cost of parental care in the woodroach Cryptocercus punctulatus Scudder (Dictyoptera: Cryptocercidae). Behav. Ecol. Sociobiol. 23: 135-140.

Nalepa CA. 1990. Life history characteristics associated with a wood diet and the evolution of termite eusociality. pp. 643644, In: GK Veekesh, B Mallik, and CA Viraktamah (eds.). Social Insect and its environment. Oxford and IBH Publishing Company PUJ, Ltd

Nelson G. 1989. Species and taxa: systematics and evolution. pp. 60-81, In: D Otte and JA Endler (eds.). Speciation and its consequences. Sinauer. Sunderland, MA.

Noirot C. 1992. From wood-to humus-feeding: an important trend in termite evolution. pp. 107-119, In: J. Billen (ed.). Biology and Evolution of Social Insects. Leuven University Press. Leuven.

Roth LM, Willis ER. 1960. The biotic associations of cockroaches. Smithson. Misc. Coll. 141: 1-470.

Schal C, Gautier JY, Bell WJ. 1984. Behavioural ecology of cockroaches. Biol. Rev. 59: 209-254.

Scrivener AM, Slaytor M, Rose HA. 1989. Symbiont-independant digestion of cellulose and starch in Panesthia cribrata Saussure, an Australian wood-eating cockroach. J. Insect Physiol. 35: 935941.

Thorne BL. 1990. A case for ancestral transfer of symbionts between cockroaches and termites. Proc. R. Soc. Lond. B 241: 37-41.

Thorne BL, Carpenter JM. 1992. Phylogeny of the Dictyoptera. Syst. Entomol. 17: 253-268.

UNESCO. 1981. Carte de la végetation d'Amérique du Sud. Notice explicative. Recherches sur les ressources naturelles XVII. Presses de l'Unesco. Paris.

UNESCO, WMO. 1975. Climatic Atlas of North and Central America. I. Maps of mean temperature and precipitation. WMO, Unesco, Cartographia.

UNESCO, WMO. 1979. Climatic atlas of north and central America. I. Maps of mean temperature and precipitation. WMO, Unesco, Cartographia.

UNESCO, WMO. 1981. WMO, Unesco, Cartographia.

White F. 1986. La vegetation del'Afrique. Recherches sur les ressources naturelles. XX. ORSTOM - UNESCO. Paris.

Whitmore TC. 1984. Vegetation of Malesia (Map). J. Biogeogr. 2.

Wilson EO. 1971. The Insect Societies. The Belknap Press of Harvard University Press. Cambridge, MA.

Ying T-S. 1983. The floristic relationships of the temperate forest 


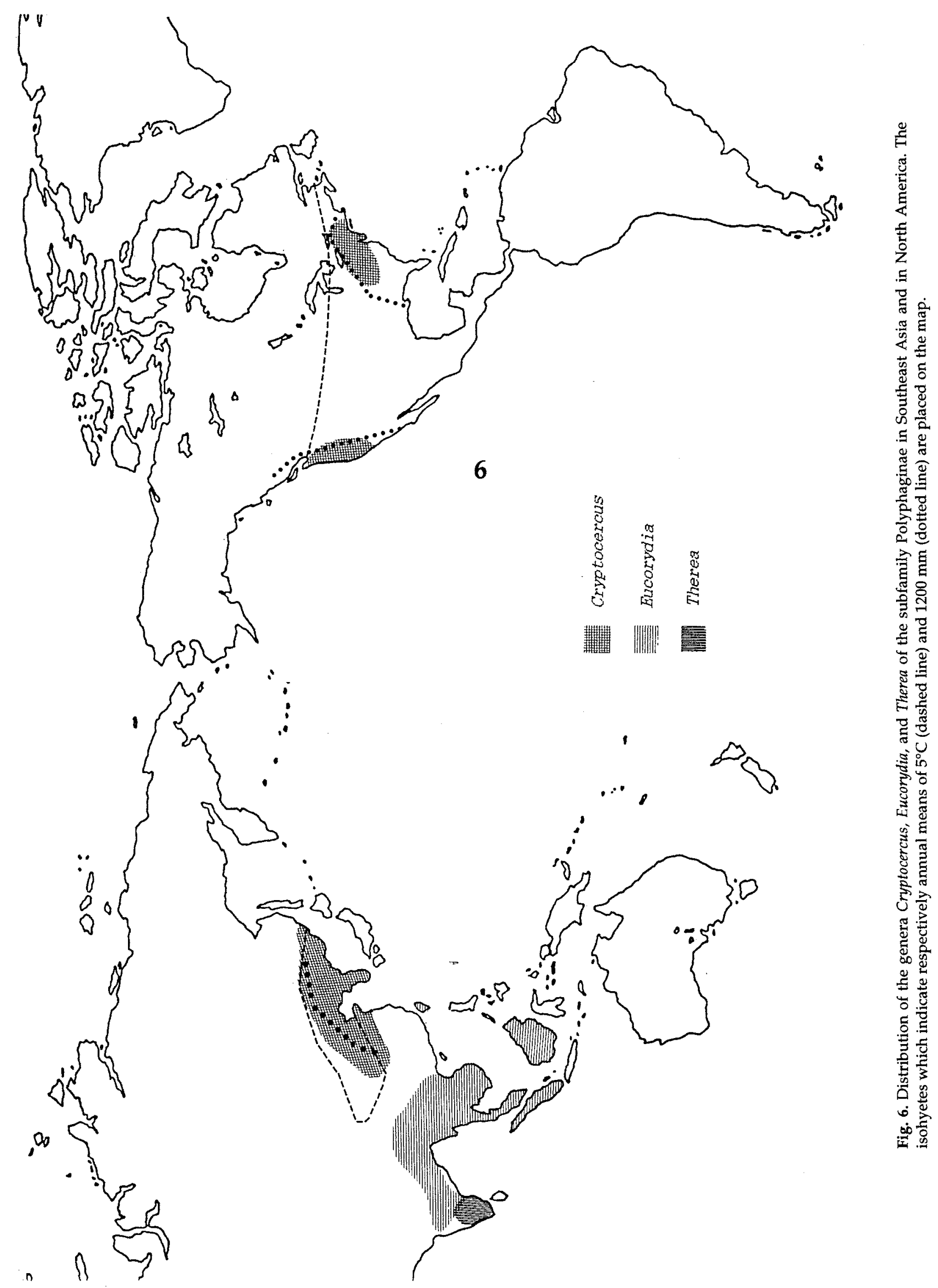

